\title{
Reflections on the Proceedings of the 19th Congress of the Chinese Communist Party (CCP) on Sino-Africa and Sino-BRICS relations
}

\section{Elias Phaahla}

Institute for Democracy, Citizenship and Public Policy in Africa

Department of Political Studies

University of Cape Town, South Africa

\section{DOI - https://doi.org/10.35293/srsa.v43i1.334}

\section{Abstract}

Beijing's economic diplomacy has, since the dawn of the millennium, sought to reconfigure the world by championing a new economic order that is predicated on the principles of multipolarity and fairness. The last policy conference of the Chinese Communist Party (CCP) shed some light into how these policy ideals are to be carried out by Beijing and how they will bear on her relationship with countries from the Global South. This paper considers the policy statements of the CCP during its 19th congress held in October 2017 as a sneak peek into the future of China's economic diplomacy and the implications for Africa's own economic future from the context of Brazil, Russia, India, China and South Africa (BRICS). It argues that China's role as the leader of the BRICS fulcrum reflects her goal to have a global influence that will see erstwhile economic backwaters such as Africa turning their focus away from the West to the East in search of sustainable solutions to their economic challenges.

Keywords: China, economic diplomacy, multi-polarity, BRICS, Chinese Communist Party 


\section{Introduction}

The 19th Congress of the Communist Party was held from 18 to 24 October 2017 and it was attended by no less than 2200 delegates from across the party structures of the Communist Party. These quinquennial occasions of the Communist Party are without a doubt the most important events in the wider body politic of the People's Republic of China (henceforth China). They are, by nature, a conclave of high-ranking and powerful power brokers within the party and the apparatus of the Chinese state to decide on the country's future from many fronts - be it economic, social and political or environmental - amongst other policy considerations. Herein the reality of the modern Chinese state is laid bare to see. The communist rule that formed the mainstay of the second quarter of $20^{\text {th }}$ century in Mao Zedong's China may at first glance appear to have been consigned to Cold War history, but its legacy reverberates strongly in the current dispensation, so much so that the modern Chinese state finds it almost impossible to shed off the character of its former self.

Bruce Gilley's work on Legitimacy and Institutional Change finds that the political system of present-day China has become something of a quasidemocracy that still holds on to its intolerant political past (Gilley 2008). It is this relatively acrimonious relationship with political liberalisation that has made it difficult for market forces in China to wrest state power entirely from the realm of the economy. Whilst it is yet to dispose completely of its Marxist-Leninist traditions, the fact that China has embraced a newfound capitalist outlook is undeniable. What is for certain is that Deng Xiaoping's vision of a China that opened its borders to the world in 1978 and undertook to fervently participate in the global economy as a necessary tool to grow the country's internal economy was sustained to generate a brand of capitalism that is unique to its own national circumstances and politico-economic history. While the notion of the state being at the centre of the running of the economy remains virtually unchanged in post-communist China, shown in part by a battery of market enhancing policies and state control (Lau 1999), China's economy is underpinned unquestionably by neoliberal principles that form the fabric of the capitalist system currently presiding over the phenomenon known as globalisation.

Against the backdrop of the shifting political and economic undercurrents in China and the international system, what can we learn from the $19^{\text {th }}$ Congress 
of the Chinese Communist Party from the economic diplomacy point of view and to what extent does it mirror Beijing's outlook towards the modern day international political and economic order? As a policy making platform, the $19^{\text {th }}$ Congress outlined China's freign policy aspirations, which will implicate directly on how Beijing conducts herself with Africa and the rest of her BRICS partners even though the two were not mentioned explicitly in the Congress' proceedings. Similarly, within the context of Beijing's engagements with the world, particularly Africa and the BRICS fulcrum as a whole, what kind of future will the $1^{\text {th }}$ Central Committee (19th CC) of the Communist Party of China herald for Beijing's economic diplomacy towards Africa within the wider context of the BRICS grouping?

This paper considers the policy statements of the Chinese Communist Party (CCP) during its $19^{\text {th }}$ congress held in October 2017 as a sneak peek into the future of China's economic diplomacy and the implications for Africa's own economic future from the context of Brazil, Russia, India, China and South Africa (BRICS). To this end, the paper commences with the Communist Party's global outlook at the turn of the millennium and the impact it has had on Beijing's quest to carve its own path in the global economy that has placed a premium on growing interdependence between nation-states. It argues that this period serves as the second watershed moment for Beijing (with the first being in 1978 when it first embarked on economic liberalisation) as it sought not only to resuscitate Deng Xiaoping's spirit of 'open door' policy, but also to make an attempt at having a dominant influence that will see China positioning itself as a global player that will offer a framework for global interdependence based on the the principles of equity, fairness and equal cooperation. The paper will then move on to address China's plurilateral and multilateral economic engagements with the African continent within the wider scheme of BRICS and what it is purposed to achieve as a grouping. Ultimately, it will argue that the resolutions of the CCP - although they make no explicit mention of BRICS and Africa - is an important statement of intent for China's economic diplomacy as it taps into economic opportunities provided by new frontiers in its quest to create a global economy that is favourable to Global South interests. Against this backdrop, it also posits that China's role as the leader of the BRICS fulcrum reflects her goal to have a global influence that will see erstwhile economic backwaters such as Africa turning their focus away from the West to the East in search of sustainable 
solutions to their economic challenges.

\section{The 19th Congress \& China's economic diplomacy after the new millennium}

Within the wider context of China's relations with other countries, the turn of the century ushered in the period of revival for the country's economic diplomacy. From Africa to Latin America, and from the Asia Pacific to the Middle East, China began flexing the muscles of its foreign economic diplomacy in ways never done by that country before. For instance, thanks to Africa's abundant mineral resources and the ever rising needs of the Chinese economy, the former was prompted to grant development aid to the countries in need in a quid pro quo style with the strict condition that they do not give diplomatic support to Taipei. By no means do we submit that China's increasing relationship with Africa is motivated my mineral resources alone as Beijing enjoys bi-lateral relations with non-mineral rich countries on the continent. China also found allure in the Middle East's own abundant oil resources, which resulted in the launch of the 'New Silk Road' initiative to regenerate trade exchanges and investments between the Persian Gulf and Asia (Summers 2016). The relationship between these two regions has grown and blossomed ever since as a result of this initiative.

Similar to the Middle East, Latin America offered China a value proposition that was based mainly on the abundant oil resources the region is endowed with as well as its vast agricultural importance for Beijing's growing food security needs. On regional home turf, China advanced to exert its influence on multilateral economic organisations during the second part of the 1990s in a bid to gain continental dominance. For instance, in 1995 Beijng started to hold annual meetings with the Association of Southeast Asian Nations (ASEAN), followed by ASEAN +3, which it initiated in 1997 comprising ASEAN countries plus China, Japan and South Korea. The ASEAN +1 mechanism followed immediately after that initiative, which saw meetings between ASEAN and China being held annually and chaired usually by the Chinese premier. China deepened its participation in the Asia-Pacific Economic Cooperation forum in 2001, which saw that country hosting the ninth leaders' meeting in Shanghai (Cheng-Chwee 2005).

Herein it becomes unquestionable that China still struggles to shed relics 
of communist control, despite having embraced openness and some elements of laissez-faire market economics as a means to spur domestic growth during chairman Deng Xiaoping's premiership. China seeks not only a participation platform, but a leadership role that would catapult it to global prominence in a bid to counter Washington's hegemonic status, which has seen a gradual decline since the turn of the century. China sought to do this not through military competition (Hodzi 2018), but rather through competing for dominance in the realm of the global economy.

But Beijing's alleged hard power aspirations are not the bone of contention here as its meteoric rise under the current international order is primarily motivated by her own quest to achieve sustainable economic growth. In fact, China's foreign economic policy is underpinned by what Michael Peters of Beijing Normal University calls the policy of "peaceful and open globalisation" based on trade (Peters 2017). Consistent with the proceedings of $17^{\text {th }}$ and $18^{\text {th }}$ congresses specifically, the $19^{\text {th }}$ congress also emphasises the importance of Beijing forging peaceful foreign relations with the rest of the world as a key ingredient to improve the material interests of the Chinese people (Ibid). Secondly it has actively used its financial prowess as a soft power tool to forge stronger relations with other countries of goodwill, especially those in the Global South. Charm and persuasion, as opposed to aggression and belligerence, remain the mainstay that gives Beijing's economic diplomacy its unique character, and it has done so in a fashion that echoes the famous Third Plenary Session of the 11th CCP when Deng Xiaoping outlined a new plan to induct China into a comity of economically 'progressive' nations back in 1978 (Shu-yun 1986). Xiaoping, the father of the modern day Chinese economy, envisioned a China whose economic ascendancy would take a peaceful course, with the semblance of humility that would assist further in the stabilisation of the international system during the turbulent period of the Cold War (Ibid).

The 19th Congress espoused ideals that reinforced these essential principles that have underpinned China's economic revival since the year of reforms in 1978. It was the first turning point moment, which saw China embracing an economic system entirely foreign to the one Mao Zedong had envisioned. While the latter frowned upon the rules of the international system, Xiaoping embraced them as a means to achieving the kind of social progress that will usher in the next phase of economic prosperity. These principles continue to reverberate 
through the social fabric of modern day China as well as through the structure of the economy. The 19th Congress saw the General Secretary of the Chinese Communist Party, Xi Jinping, being consecrated into modern-day political configurations of China through the adoption of Xi Jinping's Thought on Socialism with Chinese Characteristics for a New Era. This next phase of China's economic reforms does not depart much from those policy propositions that were adopted after 1978, which were underpinned by a modernised kind of socialism that had strong echoes of social market economics.

Certainly, this kind of socialism subscribes to the notion that human progress and market fundamentalism are sacrosanct ingredients required to realise a sustained economic future. There is no doubt that China has discharged this ideal with undeniable vigour; hence, since 1978 the rate of poverty in China has declined by 90.3 percent and through its vision, it has made 70 percent contribution to global poverty reduction (World Bank 2017). Similarly, the fact that it is the first developing country to realise the UN's Millennium Development Goal of poverty eradication is telling enough. This fact is echoed strongly in the Xi Jinping Thought, and in many ways, it serves to grant legitimacy to the socialist approach that has become the key pillar of China's economy as it strives to make its mark in a globalised world. In Xi Jinping's Thought, the focus to changing the material conditions of the Chinese people is undeniable, and the need to continue on this course is emphasised even more:

Today we, more than 1.3 billion Chinese people, live in jubilation and dignity. Our land...radiates with enormous dynamism. Our Chinese civilisation shines with lasting splendour...Our Party shows strong, firm and vibrant leadership. Our socialist system demonstrates great strength and vitality. The Chinese people and the Chinese nation embrace brilliant prospects.(Jinping 2017)

However, it is China's understanding of its position in the world that gives one a true sense of the kind of global ascendancy it is coveting which has been enhanced by the diminishing hegemonic status of the United States (Layne 2009). According to Hodzi and Yu-Wen, "the diminishing leadership role of the U.S. has provided a window of the opportunity for China to advance its own causes. Already, Chinese officials consider Beijing to be playing a prominent and 
decisive role in global affairs as the U.S. frontiers of dominance recede" (2018: 6). It is this undeniable sense of purpose, and the entitled attitude to assume one's rightful place in the world that casts China as a fierce competitor hellbent on reshaping the levers of global power and the 'rules of the game.' At the 19th Congress, Xi Jinping expressed desire for China to enter an era of ceaseless rise in the realm of the economy with the kind influence that will herald the dawn of a mutually beneficial world order that will ensure that developing countries are not left behind:

This is a new historic juncture in China's development. The Chinese nation has stood up, grown rich, and become strong - and it now embraces the brilliant prospects of rejuvenation...It will be an era that sees China moving close to centre stage and making greater contributions to mankind...The path, the theory, the system, and the culture of socialism with Chinese characteristics have kept developing countries and nations who want to speed up their development while preserving their independence: and it offers Chinese wisdom and a Chinese approach to solving the problems facing mankind. (Jinping 2017)

The Xi Thought embodies the policy direction China will be pursuing for years to come. This, along with the resolutions of the Central Committee of the CCP, offers the backstory to how Chinese economic diplomacy has been shaped and framed over the years and there is no doubt that the national congress is telling of the Party's intent to reinforce and hold on to those ideals. While it tackles a variety of considerations pertaining to modern day China - from national developmental imperatives to the country's global outlook - it offers an invaluable reference point to understanding China's economic diplomacy under the leadership of Xi Jinping towards its partners in foreign shores. Since the second decade of the 2000s, China's economic diplomacy has been punching above its weight in ways that went on to question the legitimacy of balance of forces in the realm of global economy. This is evident through the role the country plays in the BRICS grouping, which it has used to its advantage as an economic diplomacy tool to woo developing nations, including those from Africa, to enter into mutually beneficial economic partnerships. Not only is Beijing prepared to create a new world order that is predicated on principles that depart from 
those dominated by Washington and the West as a whole, it also contrives to be the leader of the very new world order it is creating using its economic strength as a useful instrument towards achieving this end. The next section weighs in on the country's economic diplomacy towards the African continent against the backdrop of the BRICS.

\section{China-Africa Relations and BRICS}

Understanding China's economic diplomacy towards Africa must be taken within the wider context of the early 2000s when the former began making bigger strides to forge stronger relations with the continent. While BRICS became complete in 2010 after the inclusion of South Africa, the turn of the millennium provides an advantageous starting point to assess the growth in maturity in the relationship between Beijing and the African continent. Of course, bilateral relations between China and Africa date back to the 1950's with Egypt becoming the first African country to forge diplomatic relations with China (Wenping 2007). But much of the period after that - and indeed for most part of the Cold War - was characterised by 'diplomatic neglect' which resulted in bilateral relations between Beijing and Africa taking a knock before intensifying after the establishment of Forum on China-Africa Cooperation (FOCAC) at the turn of the millennium. Attended by 80 foreign ministers from 45 African countries, China acted swiftly to court Africa by way of filling an economic void previously assumed by the West following their disengagement from the continent after the Cold War (Edoho 2011). By 2004, the value of China-Africa trade had jumped to 39 percent, and by 2006, China had made a series of infrastructural development pledges including the US\$500 million it pledged for a number of development projects in Ethiopia (Kwaa Prah 2007: 7). Through FOCAC, the bankrolling of investment and development projects on the continent continued unabated, resulting in the establishment of a US $\$ 5$ billion China-Africa Development Fund. And by 2015, China had delivered US $\$ 60$ billion to the continent aimed at energy and transport, which saw countries such Kenya, Ethiopia and Zambia getting the lion's share of the investment (Johnston and Rudyak 2017: 431).

But China's economic interests on the continent can be linked closely to its commitment to the BRICS grouping and the multipolar world it aims to create. Although Beijing's relations with Africa long predate the creation of BRICS, 
the emergence of the latter, however, has become even more instrumental in helping deepen the country's longstanding relationship with the continent as well as the possibility of forging new relations with those African countries that Beijing might have otherwise not been able to court with much success in the past. Although the CCP's policy pronouncements at the $19^{\text {th }}$ Congress implied unwavering commitment to the BRICS agenda, to assume that China has relegated BRICS to the side-lines of its priorities would be grossly erroneous. $\mathrm{Xi}$ Thought makes all-encompassing policy pronouncements that transcend various facets of policy priorities, requiring that it be read in the context of recent developments in the international system in which China is an active participant. Multipolarity and peaceful multilateralism feature prominently on the policy statements of the Xi Thought, which have echoes of the last BRICS Summit held in Xiamen, in which China placed a lot of emphasis on 'win-win', cooperation, and equality amongst other considerations (BRICS 2017).

Just prior to that, China had proposed the notion of BRICS+, which is a shorthand for an expanded BRICS membership that will add to the existing five member states. It is worth considering at this stage that China's proposition, although failing to obtain the necessary consensus for it to pass, also sought to include a number of African countries whose economies hold the promise of helping to advance the overall mandate of the BRICS. Had this proposition received an unequivocal greenlight from other BRICS countries, it would have fulfilled China's long-held ambition to garner the requisite support that would enhance its global standing as the leader of the Global South and ultimately succeed in the quest to reconfigure the global levers of power. Speaking in Addis Ababa on the occasion of the Second Ministerial Conference of the China-Africa Cooperation in December 2003, the then Prime Minister of China, Wen Jiabao, expressed China's intent to get Africa behind it in the pursuit of this agenda: "China is ready to co-ordinate its positions with African countries in the process of international rules formulation and multilateral trade negotiations" (FMPRC 2003). These words reinforce Hodzi and Yu-Wen's assertions that China is a "revisionist power seeking to challenge the existing international order so as to establish a parallel order, or, at least, materially revise the existing one" (Hodzi and Yu-Wen 2018: 7).

The inclusion of South Africa into the group, which came at the behest of China to make up BRICS, became a powerful economic bloc accounting for 20 
percent of global GDP (Tralac, 2014). The fact that China successfully lobbied for the inclusion of South Africa into the alliance is telling of the economic clout it has in the BRICS alliance and it is further telling of the influence it wishes to exert as a de facto leader of the Global South. Furthermore, having the latter included in the grouping served the strategic importance of legitimising Beijing as an ally that has the best interest of the continent at heart.

For a while now, South Africa has always been viewed by the rest of the world as the entrepot to the African continent, owing largely to the sophistication of her economy, the size of its gross domestic product (GDP) (as largest on the continent at the time of joining BRICS), good infrastructure, and the promise of success and results-driven cooperation its economy offered. The case Beijing made for South Africa's inclusion most probably followed this logic, which is a success for the country's economic diplomacy given that it managed to galvanise most (if not all) significant economic players from strategic geopolitical regions in the global South to rally behind it. Although China has been engaging with China prior to the South Africa's ascension to BRICS, one can argue that bringing the former into the mix was an attempt at having the already existing relationship with the continent deepened further. Similarly, and as it will be shown in the section to follow, China's economic relationship with the continent began intensifying in the second decade of the millennium either in the form of trade, development assistance (aid) or loans even though it had begun doing the works during the first decade of the 2000s.

\section{Beijing's aid, trade and investment charm offensive}

To Beijing Africa has offered a value proposition that necessitated - from the economic standpoint - the kind of capital injection that will position Beijing as a dependable ally of the continent with genuine interest to help unlock its economic potential. It has in many ways embarked on a drive to delegitimise Africa's traditional economic partners from the West. Indeed in practice Beijing has kept its share of the bargain with its foreign investments on the continent flowing rapidly since the turn of the century. For instance, the meagre $\$ 10$ billion China invested on the continent in 2000 have since seen a 20 -fold increase to $\$ 220$ billion in 2014 according to the China Africa Research Initiative (CARI) at the School of Advanced International Studies (SAIS) at Johns Hopkins University (CARI 2017). Along the same lines, Beijing has invested in a number 
of railway and port construction projections in East Africa aimed at facilitating the continent's participation in the so-called Maritime Silk Route which forms the basis of Beijing's inclusion of mainly the East Coast of Africa into the One Belt One Road (OBOB). Examples include the planned $759 \mathrm{~km}$ route Addis Ababa-Djibouti railways to the cost of US $\$ 4.5$ billion, the US $\$ 11$ billion for the construction of a port in Bagamoyo, Tanzania, and the recently completed Nairobi-Mombasa railway, said to have come at the cost of US $\$ 3.2$ billion (Edinger and Labuschagne 2019: 7).

The same level of commitment is also demonstrated in the value of trade between Beijing and the African continent as reported by the Financial Times of London, amongst other publications (Financial Times 2017). Relative to the value of trade exchanged between the continent and the United States since the first decade of the 2000s, the value of trade between China and the continent has risen steadily, only coming second after the United States. As shown in the diagram below, the tables began to turn during second decade of the 2000s, which saw the value of trade between China and the continent, surpassing that with the United States. Although the value of trade between Africa and China dropped severely from the over US $\$ 220$ billion peak of 2015 , to under US $\$ 150$ billion in 2017 , it far surpasses the US $\$ 49$ billion that makes up overall US-Africa trade.

\section{Chinese and US trade with Africa}

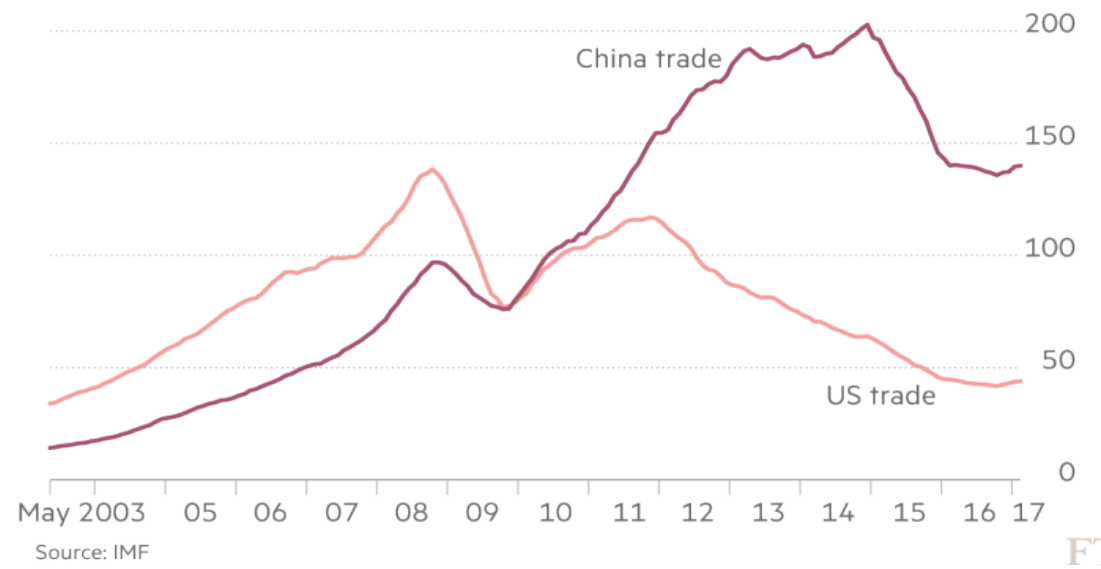

Figure 1 
Source: Financial Times (2017)

The nature of China-Africa trade is subject to various interpretations, many of which speak to the growing importance of the continent to China's long-term economic interests. The first six years of the millennium saw China importing a slightly higher number of goods from Africa than it exported to the continent (Moyo 2016). Although the year 2007 saw a change in this pattern, with Beijing importing less goods before the 2000s, 2008 saw a slight resurgence of imports in China despite the sharp economic decline that gripped the world economy with imports mainly dominated by oil (CARI 2017). Table 1 shows that this trend in Sino-Africa trade continued well into 2009 with Angola emerging as China's top trade partner in Africa and whose oil production only came second after Nigeria, as shown in Table 2. By 2018, the situation had barely changed save for South Africa replacing Angola as Africa's top trading partner followed closely by oil producers such as Nigeria, Egypt and Algeria respectively, according to China's Ministry of Commerce (MOFCOM) (ECNS 2018). Nevertheless, the number of exports from Africa to China took a meteoric rise, with the value of Chinese exports to the region reported as having peaked from US $\$ 92$ billion in 2013 to US\$120 billion in 2017 according to CARI.

Table 1: China's top trade partners relative to overall Sino-Africa trade, 2009 \& 2018 (Percentage)

\begin{tabular}{lll}
\hline & Percentage (\%) \\
\hline Country & 2009 & 2018 \\
\hline South Africa & 17,6 & 21,3 \\
\hline Angola & 18,7 & 13,7 \\
\hline Congo & 2,3 & 3,5 \\
\hline Congo, DR & 1,6 & 3,6 \\
\hline Equitorial Guinea & 1,5 & 1,1 \\
\hline Nigeria & 6,9 & 7,4 \\
\hline Sudan & 7,0 & 1,2 \\
\hline Zambia & 1,5 & 2,4 \\
\hline
\end{tabular}

Source: Estimates and calculations by author (National Bureau of Statitics, 2009 \& 2018) 


\section{Table 2: Oil production and reserves in Africa}

\begin{tabular}{lll}
\hline Country & Production * (bbl/day) & Proven reserves** 000 's barrels) \\
\hline Nigeria & $2,211,000(15)$ & $37,500,000(10)$ \\
\hline Angola & $1,948,009(17)$ & $13,500,00(15)$ \\
\hline Sudan & $486,700(31)$ & $8,800,000(20)$ \\
Congo, Republic of the & $274,400(39)$ & $1,600,000(37)$ \\
\hline Gabon & $241,700(41)$ & $2,000,000(35)$ \\
South Africa & $191,000(43)$ & $15,000,000(87)$ \\
Chad & $115,000(51)$ & $1,500,000(39)$ \\
Cameroon & $77,310(55)$ & $200,000(58)$ \\
Cote d'Ivoire & $58,950(60)$ & $250,000(57)$ \\
Congo, Democratic Republic of the & $16,360(78)$ & $180,000(61)$ \\
\hline
\end{tabular}

* Production figure is for 2009

** Proven reserves as of 29 April 2011

Figures in parentheses are world rankings

Source: CIA World Factbook (in Edoho, 2011: 114)

However, these trends still leave an important question hanging in the air; how does China-Africa trade compare to China-BRICS trade as a whole? Further, how significant is the trade volume between China and the respective regions represented by each one of the BRICS member states? Compared to Asia, which trades the most with China of all regions represented by a BRICS member state, Africa seems to be trading the least with China, with Sino-South Africa trade accounting for only 27,18 percent of the overall China-Africa trade in 2014, a figure that marginally declined to 25,7 percent in 2015. Table 3 also shows that when compared with the rest of the BRICS countries, China trades with Africa the least, with overall China-Africa trade in 2014 accounting for 6,2 percent of China-BRICS trade, a figure that declined to 5,5 percent the following year. These estimates are a far cry from figures showing China-Asia trade, which account for 64,3 percent of overall China-BRICS trade for 2015, a marginal decline from 65,3 percent of 2014. Also, the volume of bilateral trade between China and Africa contracted significantly from US $\$ 28$ billion in 2005 (Alden 2005) to a little over US $\$ 20$ billion in 2018 as shown in Table 5, which represented a drop of 28.5 percent. 
Table 3: Value of Chinese trade with BRICS countries relative to their respective regions, $2014-2015$ (US\$ 10000 )

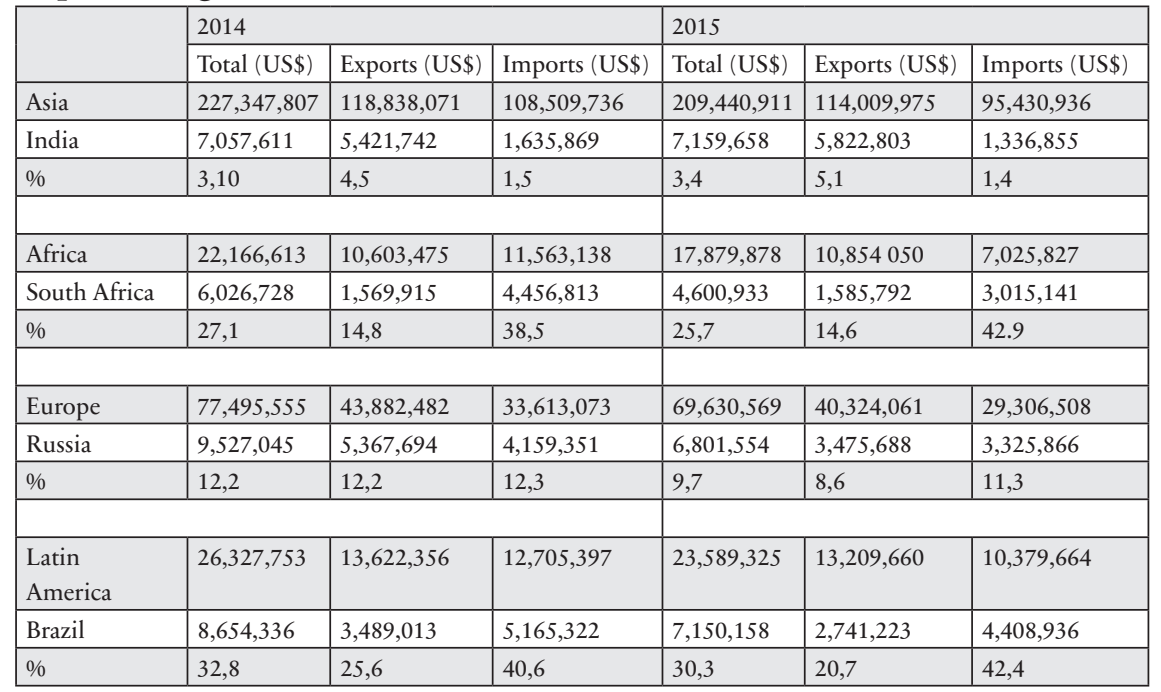

Calculations and estimates by author (Source: National Bureau of Statistics of China, 2014 \& 2015)

\section{Table 4: Value of Chinese trade with BRICS countries relative to their} respective regions, 2016 - 2017 (US\$ 10000 )

\begin{tabular}{|c|c|c|c|c|c|c|}
\hline & \multicolumn{3}{|l|}{2016} & \multicolumn{3}{|l|}{2017} \\
\hline & Total (US\$) & Exports (US\$) & Imports (US\$) & Total (US\$) & Exports (US\$) & Imports (US\$) \\
\hline Asia & $194,691,029$ & $104,111,685$ & $90,579,344$ & $212,652,448$ & $109,634,007$ & $103,018,441$ \\
\hline India & $7,017,947$ & $5,841,534$ & $1,176,413$ & $7,159,658$ & $5,822,803$ & $1,634,537$ \\
\hline$\%$ & 3,6 & 5.6 & 1,3 & 3,41 & 5,1 & 1,5 \\
\hline Africa & $14,896,190$ & $9,227,200$ & $5,668,990$ & $17,064,477$ & $9,471,762$ & $7,592,715$ \\
\hline South Africa & $3,508,242$ & $1,285,352$ & $2,222,889$ & $3,919,736$ & $1,480,877$ & $2,438,860$ \\
\hline$\%$ & 23,5 & 13,9 & 39,2 & 22,9 & 15,6 & 32,1 \\
\hline Europe & $67,776,336$ & $38,991,655$ & $28,784,681$ & $75,610,675$ & $42,897,540$ & $32,713,136$ \\
\hline Russia & $6,961,592$ & $3,735,527$ & $3,226,015$ & $8,422,089$ & $4,283,060$ & $4,139,029$ \\
\hline$\%$ & 10,2 & 9,5 & 11,2 & 11,1 & 9,9 & 12,6 \\
\hline Latin America & $21,700,736$ & $11,393,614$ & $10,307,123$ & $25,859,012$ & $13,081,617$ & $12,277,394$ \\
\hline Brazil & $6,783,432$ & $2,197,927$ & $4,585,505$ & $8,780,769$ & $2,895,054$ & $5,885,716$ \\
\hline$\%$ & 31,2 & 19,2 & 44,4 & 33,9 & 22,1 & 48,1 \\
\hline
\end{tabular}

Calculations and estimates by author (Source: National Bureau of Statistics, 2016 \& 2017) 
Table 5: Value of Chinese trade with BRICS countries relative to their respective regions, 2016 - 2018 (US\$ 10000 )

\begin{tabular}{|l|l|l|l|}
\hline \multirow{2}{*}{} & \multicolumn{3}{l}{} \\
\cline { 2 - 4 } & Total (US\$) & Exports (US\$) & Imports (US\$) \\
\hline Asia & $238,058,298$ & $118,759,869$ & $119,298,429$ \\
\hline India & $9,550,900$ & $7,667,566$ & $1,883,335$ \\
\hline$\%$ & 4 & 6,4 & 1,5 \\
\hline \multicolumn{5}{|l}{} \\
\hline Africa & $20,415,879$ & $10,489,386$ & $9,926,493$ \\
\hline South Africa & $4,353,589$ & $1,624,838$ & $2,728,749$ \\
\hline$\%$ & 21,3 & 15,4 & 27,4 \\
\hline \multicolumn{5}{|l}{} \\
\hline Europe & $85,403,048$ & $47,559,772$ & $37,943,276$ \\
\hline Russia & $10,710,745$ & $4,796,527$ & $5,914,218$ \\
\hline$\%$ & 12,5 & 10 & 15,5 \\
\hline \multicolumn{5}{|l}{} \\
\hline Latin America & $30,717,170$ & $14,877,758$ & $15,839,412$ \\
\hline Brazil & $11,123,439$ & $3,366,487$ & $7,756,952$ \\
\hline$\%$ & 36,2 & 22,7 & 48,9 \\
\hline
\end{tabular}

Calculations and estimates by author (Source: National Bureau of Statistics, 2018)

Looking at Table 1, 2 and 3 combined, it would not be far-fetched to surmise that oil remains at the centre of China-Africa trade, a reality corroborated by the fact that China's top trading partner in the region is Angola, Africa's second largest oil producer. Although China-Africa trade shows that South Africa also accounts for quite a sizable percentage of the value of trade between Beijing and Africa, the trends show that things have not changed much from trade estimates shown in Table 1 with the exception of Angola, which was leapfrogged by South Africa as China's top trading partner in SSA. Bilateral trade between China and Sudan has dropped significantly, but that is ascribed to the protracted political conflict in Sudan as opposed to reduced appetite for oil by Beijing.

The relatively low levels of trade between the two member countries of BRICS, i.e. South Africa and China, are without a doubt symptomatic of the unevenness and unequal nature of China-Africa trade as a whole, which has given primacy to oil to the benefit of China's economy in the long run as shown in Table 2. Compared to China-BRICS trade, China-South Africa trade fell sharply from a buoyant 27 percent as a proportion of China-Africa trade to a worryingly low level of 21.3 percent between 2016 and 2018, as shown in Table 5. Meanwhile, South Africa has on average contributed 36 percent of China's total imports from 
Africa since 2014, with imports from the former contracting to 32 per cent in 2017 as a proportion of China-Africa trade and falling yet further to 27.4 percent in 2018.

Table 6: Africa-BRICS Trade Categorised by Product, 2016

\begin{tabular}{|l|l|l|}
\hline Product Code & Gross Exports & Gross Imports \\
\hline Food \& live animals & $\$ 2,505,760$ & $\$ 11,299,454$ \\
\hline Beverages \& tobacco & $\$ 971,208$ & $\$ 649,459$ \\
\hline Crude materials, inedible, except fuels & $\$ 3,350,176$ & $\$ 1,722,330$ \\
\hline Mineral fuels, lubricants and related materials & $\$ 13,444,084$ & $\$ 5,241,207$ \\
\hline Animal \& vegetable oils, fats and waxes & $\$ 39,776$ & $\$ 593,275$ \\
\hline Chemicals and related products n.e.s & $\$ 2,289,344$ & $\$ 9,398,479$ \\
\hline Manufactured goods classified chiefly by material & $\$ 2,463,633$ & $\$ 19,553,536$ \\
\hline Machinery and transport & $\$ 564,243$ & $\$ 29,817,547$ \\
\hline Miscellaneous manufactured articles & $\$ 343,618$ & $\$ 7,400,247$ \\
\hline $\begin{array}{l}\text { Commodities and transactions not classified } \\
\text { elsewhere in the SITC }\end{array}$ & $\$ 4,900,232$ & $\$ 246,212$ \\
\hline Total & $\$ 30,872,073$ & $\$ 85,921,746$ \\
\hline
\end{tabular}

Source: Dodd (2019:78)

If it is true that China's top trading partners in Africa comprise mainly oil and mineral-rich countries as Table 1 suggests, then these estimates imply that the value of Africa as China's trading partner is disproportionately reliant on its vast mineral and oil endowment with very little prospects for the latter to forge strong trade relations with non-oil and minerals exporters in sight. And if the foregoing observation is anything to go by, it begs a number of questions concerning the nature and quality of Sino-Africa trade and its bearing on BRICS-Africa relations in years to come. Others concern whether China's strangehold on the continent leaves room for Africa-BRICS trade relationship that is less dependent on mineral fuels and related materials as Table 6 suggests. Additionally, one is tempted to ponder the extent to which BRICS might be used as a legitimacy building instrument to expand Beiing's presence on the continent.

\section{Conclusion}

Beijing's quest for the creation of a multipolar world order has inadvertently cast it as the champion of pro-Global South interests. This new-found sense of responsibility has seen it forge strong relations with developing countries, 
including working cheek-by-jowl with many countries from Africa to change their economic circumstances through various schemes and initiatives aimed at boosting their economies. Owing to an increase in economic activity between China and Africa since the advent of the millennium (either in the form of trade, loans and development assistance), there is no doubt that China is intent on positioning itself as an active participant within the realm of the global economy and assuming the global leadership that it feels it deserves. However, China does not want to do this alone, and in fact, it does not see reasonable prospects of it materialising without her unofficial enthronement as a bona fide champion of the Global South. For China, BRICS offers the opportunity to get the process of rallying countries from the Global South behind her as a well-oiled vehicle to pursue that ambition with vigiour.

While the proceedings of the $19^{\text {th }}$ congress make no explicit mention of SinoAfrica relations, or China's relationship with the rest of the BRICS countries, the policy outcomes of the congress will have far reaching implications for both. BRICS will remain central to China's economic diplomacy, which relies heavily on maintaining goodly relations with other Global South countries, and there is no doubt that that equation has set sights on Africa as an important consideration. The many strides China has made on the continent - be it in the form trade or investments, amongst others - were designed from the outset to serve as legitimacy-building tools to bolster its image as a reliable friend of the continent that has the best interests of Africa at heart. Moreover, the fact that China successfully lobbied for the inclusion of a relatively insignificant economy of South Africa vis-a-vis other members of the fulcrum served to give credence to suspicions of Beijing's relentless drive to enhance its legitimacy for the express purpose of expanding yet further its presence on the continent.

This paper demonstrated the nature of Sino-Africa relations at the time when BRICS has set out to change the levers of power in the realm of the global economy against the backdrop of the 2017 conference resolutions of the Chinese Communist Party. Three years on, BRICS remains an important part of the Chinese equation tipped to safeguard the interests of both African countries and Beijing in the process. It showed that while strides were made to diversify BRICS-Africa trade, trade between BRICS and the continent remains stubbornly dominated by mineral resources, a fact that may in many ways be a function of Sino-Africa trade being dominated by the same. The jury is still out to see how 
this would have affected Chinese economic diplomacy towards Africa when it hosts the next policy conference in 2022 and the extent to which BRICS-Africa relations will reflect Bejing's current policy proclamations and those to come in the future.

\section{References}

Alden, Chris. 2005, “China in Africa." Survival 47(3):147-164. https://www. tandfonline.com/doi/pdf/10.1080/00396330500248086?needAccess=true

BRICS. 2017. "Brics leaders Xiamen declaration”, September 5. http://www. bricschn.org/English/2017-09/05/c_136583711.htm.

CARI. 2017. “Data: China-Africa Trade”, November 12. http://www.sais-cari.org/ data-china-africa-trade

Cheng-Chwee, Kuik. 2005. "Multilateralism in China's ASEAN Policy: Its evolution, characteristics, and aspiration." Contemporary Southeast Asia 22(1):102-122. https://muse.jhu.edu/article/387932/pdf

ECNS. 2018. "China-Africa in numbers: trade ties”, September 04. http://www. ecns.cn/news/economy/2018-09-04/detail-ifyxpqun1875058.shtml.

Edinger, Hannah and Labuschagne, Jean-Pierre. 2019. “China's role in African infrastructure and capital projects.” Deloitte Insights, May 28. https://www2. deloitte.com/us/en/insights/industry/public-sector-china-investment-africainfrastructure -development.html.

Edoho, Felix. 2011. "Globalisation and marginalisation of Africa; contextualisation of China-Africa relations." Africa Today 58(1):104-124. https:// www.jstor.org/stable/pdf/10.2979/africatoday.58.1.103.pdf?refreqid=excelsior\%3A6a187b48292602566bb1a9e7143d2feb

Financial Times. 2017. "Chinese investments in Africa: beijing's testing ground." June 13. https://www.ft.com/content/0f534aa4-4549-11e7-8519-9f94ee97d996.

FMPRC. 2003. "Address by H.E. Mr. Wen Jiabao Premier of the State Council of the People's Republic of China at the Opening of the Second Ministerial Conference of the China-Africa Cooperation Forum”, December 15. https:// www.fmprc.gov.cn/zflt/eng/zyzl/zyjh/t157711.htm.

Gilley, Bruce. 2008. "Legitimacy and Institutional Change: The Case of China." Comparative Political Studies 41(3):259-284. https://journals.sagepub.com/doi/ pdf/10.1177/0010414007308020. 
Hodzi, Obert. 2018. "Delegitimization and 'Re-socialisation': China and the Diffusion of Alternative Norms in Africa." International Studies 55(4):297-314. https://journals.sagepub.com/doi/pdf/10.1177/0020881718805215.

Hodzi, Obert and Yu-Wen, Chen. 2018. "Following the Flor: China's Approach to Global Leadership." China Quarterly of International Strategic Studies 4(1):1-21. https:/www.worldscientific.com/doi/epdf/10.1142/S2377740018500045.

Jinping, Xi .2017. “Secure a decisive victory in building a moderately prosperous society in all respects and strive for the great success of socialism with Chinese Characteristics for a new era." Xinhuanet. October 8. http://www.xinhuanet. com/english/download/Xi_Jinping's_report_at_19th_CPC_National_ Congress.pdf.

Johnson, Lauren and Rudyak, Marina. ed. 2017. China's 'innovative and pragmatic' foreign aid: shaped by and now shaping globalisation. Acton: Australian National University Press

Kwaa Prah, Kwesi. ed. 2007. Introduction: defining a relationship. Cape Town: CASAS

Wenping, He. ed. 2007. 'All weather friend': The evolution of China's African policy. Cape Town: CASAS

Lau, W.K. 1999. "15th Congress of the Chinese Communist Party: Milestone in China's Privatisation.” Capital \& Class 23(2):57-87. https://journals.sagepub. com/doi/pdf/10.1177/030981689906800105

Layne, Christopher. 2009. "The waning of U.S. hegemony - myth or reality?” International Security 34(1):147 - 172. http://www.ir.rochelleterman.com/sites/ default/files/Layne2009.pdf.

Moyo, Sam. 2016. "Perspectives on South-South relations: China's presence in Africa" Inter Asia Cultural Studies 17(1):58-67.https:/www.tandfonline.com/ doi/pdf/10.1080/14649373.2016.1138615?needAccess=true.

National Bureau of Statistics of China. 2015. "Value of imports and exports by country (region) of origin/destination” http://www.stats.gov.cn/tjsj/ndsj/2015/ indexeh.htm.

National Bureau of Statistics of China. 2016. "Value of imports and exports by country (region) of origin/destination", http://www.stats.gov.cn/tjsj/ndsj/2016/ indexeh.htm.

National Bureau of Statistics of China. 2017. "Value of imports and exports by country (region) of origin/destination", http://www.stats.gov.cn/tjsj/ndsj/2017/ 
indexeh.htm.

National Bureau of Statistics of China. 2018. "Value of imports and exports by country (region) of origin/destination”, http://www.stats.gov.cn/tjsj/ndsj/2018/ indexeh.htm.

Peters, Michael.A. 2017. "Editorial: The Chinese Dream: Xi Jinping thought on socialism with Chinese characteristics for a new era." Educational Philosophy and Theory 49(14):1299 - 1304. https://www.tandfonline.com/doi/ pdf/10.1080/00131857.2017.1407578?needAccess=true.

Shu-yun, Ma. 1986. "Recent changes in china's pure trade theory." The China Quarterly 106:291 - 305. https://www.jstor.org/stable/pdf/653432. pdf?refreqid=excelsior\%3A8a8f7c3722123616bf989915e8d00013.

Summers, Tim. 2016. "China's 'new silk roads' initiative: sub-regional regions and networksofglobaleconomy”'ThirdWorldQuarterly37(9):1628-1643.https://www. tandfonline.com/doi/epub/10.1080/01436597.2016.1153415? needAccess=true.

Tralac. 2014. "BRICS economies not crashing: economist." https://www.tralac. org/news/article/5415-brics-economies-not-crashing-economist.html.

World Bank. 2017. "Country Overview: China." http://www.worldbank.org/en/ country/china/overview. 